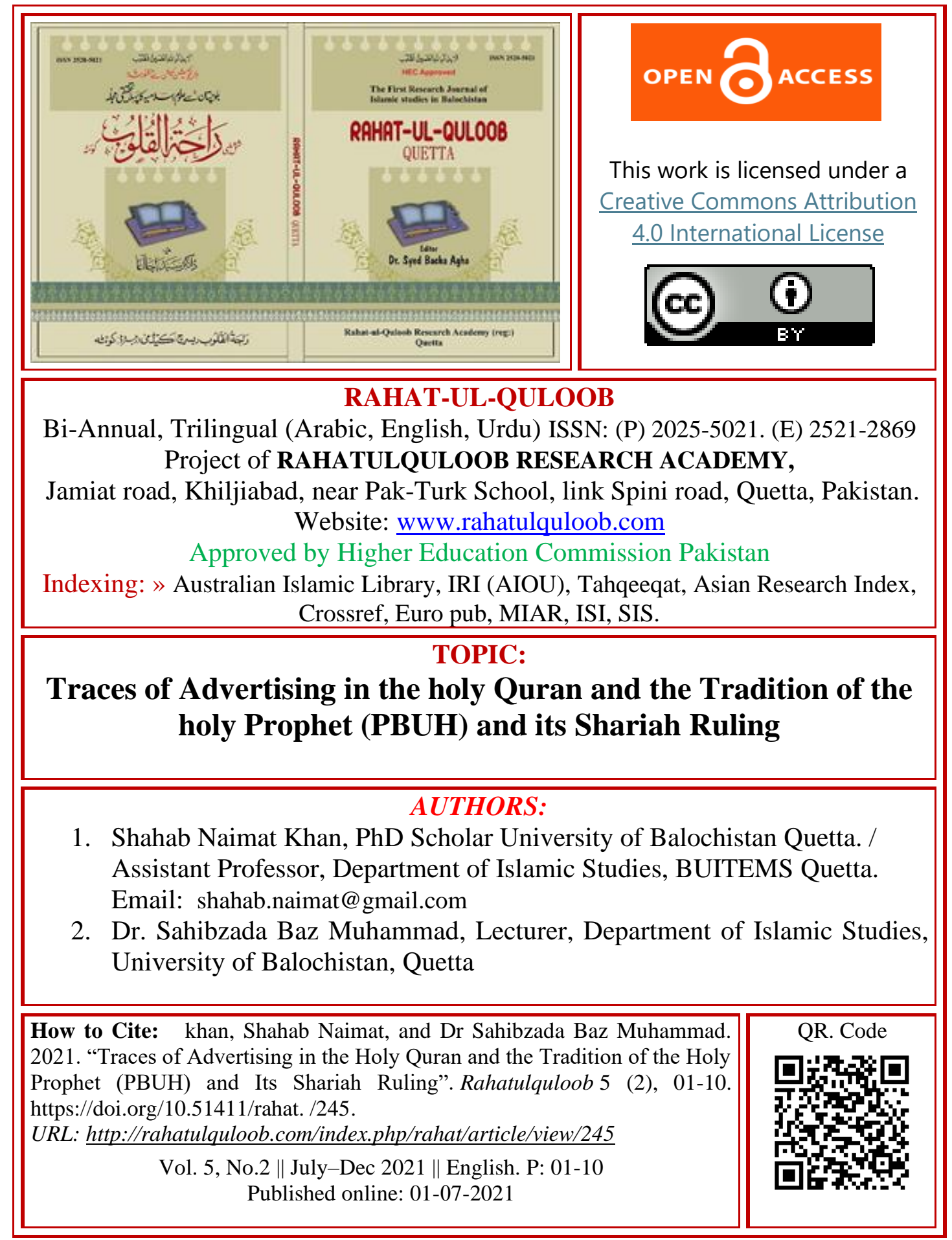




\section{Traces of Advertising in the holy Quran and the Tradition of the holy Prophet (PBUH) and its Shariah Ruling}

\section{ABSTRACT:}

${ }^{1}$ Shahab Naimat Khan, ${ }^{2}$ Sahibzada Baz Muhammad

Islam guides its followers in every field of life. It requires from Muslims to search solutions of emerging problems keeping in view the golden rules set by the Quran and the Sunnah. Advertising along with its recent ways is somehow a new phenomenon. This study aims to explore antecedences of advertising in the holy Quran and the Traditions of the holy Prophet. (PBUH) Firstly, the two meanings of advertising are mentioned, and the examples of both meanings are presented from the Quran, the Traditions of the holy Prophet (PBUH) and the life of one of the holy companions of the Prophet. Secondly shariah ruling of the advertising is discussed in the light of the sources of the shariah. Lastly the results of the study are stated that read: Keeping in view the cases of the advertising from the Traditions of the holy Prophet (PBUH) and bearing in mind importance and need of it in current times, it is clear that publishing ads and broadcasting them for the promotion of the goods or services is basically allowed unless something contradictory to Islam is added to it, like lies, deception, exaggeration, degrading of other's goods and display of half-naked women etc.

Keywords: Elaan, Ishtihar, Daff, Samasira, Islamic Shariah

\section{Introduction}

Islam is a 'Deen' that guides its believers in every field of life with clear-cut directives and does not leave them in the lurch. Therefore, Islam requires from Muslims that if they are stuck in a situation where they do not find any solution, they should consult the teaching of the Holy Quran and the Prophet Muhammad (Peace and Mercy be upon him) and seek answers there. Allah the Almighty says: "If you differ about anything, refer it to Allah and the Messenger, if you truly believe in Allah and the Last Day, this is better and most commendable in the end."

Similarly, Allah the Sublime says: "And when there comes to them a matter of peace or fear they spread it around, If they had referred it to the holy Messenger and those who have authority among them, indeed those who were given reasoning would have understood it (and could have made correct deductions) and if the grace of Allah and His mercy were not upon you, you would have followed Satan excepting a few."2

It is a duty of a Muslim to consult the holy Quran, the Hadith and the knowledgeable people whenever he faces a new issue or there appears new case of an old issue. Keeping in view this point here in this article it is tried to find traces and precedence in the teachings of the Quran and the Tradition of the holy Prophet (PBUH) regarding the "Advertising". Furthermore, it is strived to know the shariah ruling of the current Advertising and its novel situations in the light of those traces and examples.

This article is divided into three main headings. First heading goes 'Advertising in Prophet Era'. It is discussed that the Advertising as announcement was present in the 
time of holy Prophet Muhammad (Peace and Mercy be upon him). Further in this heading six examples are quoted from the traditions of the holy Prophet (PBUH) and one is stated from the holy Quran and contains reference to the life of Noah (PBUH). Second heading reads 'Commercial Advertising in the Prophet Era'. Five traces are mentioned under this second heading from the ahadis of the holy Prophet (PBUH) and a story of Hazrat Ali (May Allah be pleased with him) is added later. Third heading talks about the Shariah Ruling of the Advertising in the light of the holy Quran, the Hadith and the Jurisprudence. The results of the discussion are summarized in the end.

\section{Advertising in the Prophet Era}

The Arabic word "Elaan" is used in two meanings nowadays: Firstly, it is used when there is a relation between a manufacturer of a product and consumers and the goal of this relation is to enhance sale of the product. Secondly, it is utilized where someone needs to guide people in some issue or attain a specific objective. ${ }^{3} \mathrm{He}$ spreads the message widely.

That Arabic word 'Elaan' currently is translated into English language as 'Advertising'. The second meaning of the word 'Elaan' is 'Announcement' in English. ${ }^{4}$ Urdu Language of the present times translates the word 'Advertising' as 'Ishtihar' which means 'Commercial Adverting' and translates the word 'Elaan' as announcement.

\section{Elaan as an Announcement in the Prophet Era}

The examples of the second meaning i.e. Elaan are being mentioned here.

\section{Story of Suraqa bin Malik}

The Qureshities advertised that whosoever assassinates Muhammad (PBUH) or Abu Bakar or brings them alive, he will be rewarded with one hundred camels on each one of them. ${ }^{5}$ Suraqa bin Malik himself narrates that a messenger of the Qureshities came to us and gave news that whoever kills Muhammad (PBUH) or Abu Bakar or brings them alive he will receive one hundred camels as reward for the each. I was sitting in one of the gatherings of my tribe Banu Mudlij and a man came and shouted among us: O Suraqa! I have just seen a caravan heading to the beach. I guess they were Muhammad (PBUH) and his fellows. Suraqa says: I knew they were there but I said to him: Surely, they are not the ones rather you have seen so and so who left right before us. I stayed there for a moment and came later. I entered my home and said to my maid servant: Get my horse ready and take it to that mound and wait for me there. I took my spear and left from the back of my house. I hid the spear fearing others to see. Came near to the horse and rode it. The horse carried me to them. As I approached them my horse fell with me. I extended my hand to a quiver to have an arrow for omen. I wanted to know whether I should harm them or not. There was an ill omen that I did not like. I rode my horse again and went against the omen. I reached nearer to them as I could listen to the recitation of Muhammad (PBUH). He did not pay any attention to me, whereas Abu Bakar was watching me time and again. The two hands of the horse sank into the earth and I fell. I scolded the horse and he stood up. He had not gotten his hands out yet, but the dust of his legs covered the sky. I took advised 
from the omen the second time, but the result was against my wish. At that moment I asked for their refuge. They stopped and I came closer to them. Because of all what I experienced, said to myself that the status of Muhammad (PBUH) undoubtedly will appear. I said to them: Your nation has given an advertising that there is reward on you of one hundred camels. I added those points which people of Makkah desired against them. I wanted to gift them my viaticum, but they did not accept. Moreover, they said: 'Do not tell people about us.' To be sure, I pleaded them to write an agreement for me. The holy Prophet (PBUH) ordered Amir Bin Fahira to write. He took a piece of skin and wrote peace agreement. The Messenger of Allah (PBUH) left afterwards. ${ }^{6}$ The aforesaid story is a clear evidence of advertising as announcement before Islam. It was used to convey a message to masses or attain some specific purpose.

\section{Announcement for Qureshities of Makkah}

Earlier to the battle of Badr, when the holy Prophet Muhammad (PBUH) set off with his army to attack the caravan of Abu Sufyan (who had not accepted Islam yet) and Abu Sufyan came to know about this move, he hired Zumzum bin Amr Ghaffari and sent him to the Qureshities to announce (to do Elaan) that Muhammad (PBUH) and his army had planned to invade their commercial caravan, hence they should come forward to protect it. As soon as they heard this Elaan (announcement) they stood up and started preparation for the battle....?

Here the word "Elaan" means "Announcement".

\section{Azaan as Elaan}

The most important thing after accepting Islam is Salat (the Prayer). The holy Prophet (PBUH) adopted 'Azaan' for inviting Muslims to the Prayer. Azaan is an announcement that the time of the prayer has commenced, and all Muslims should come for the prayer. Furthermore, wording of Azaan contains the announcement of the following points:

a. The greatness of Allah the Sublime when said: اللهأكبر

b. Unity of Allah the Almighty and rejection of any partner with Him. أشهدأب لا إله إلا الله

c. Prophethood of Muhammad (PBUH): أشهد أسبـمحمدارسول الله

d. Invitation to the most significant worship of Islam: حى على الصلاة

e. Call for the eternal success:

f. The greatness and Unity of Allah the Merciful is repeated in the end: البه أكبر، لا إله إلا الله

There is a connotation of Elaan in the meaning of an announcement in Azaan.

\section{Story of Kaab bin Malik (May Allah be pleased with him.)}

The famous hadees of Hazrat Kaab bin Malik (MABPWH) is narrated in both Sahih 
Bukhari and Muslim. Other books written on the biography of the holy Prophet (PBUH) also contain that hadees. Hazrat Kaab bin Malik did not participate in the battle of 'Tabook'. When the holy Prophet (PBUH) was back along with his companions, the people who had set back and did not join them in the battle came to the holy Prophet (PBUH) and presented their excuses. The holy Prophet (PBUH) neither got angry with them nor say them anything. I determined to speak the truth and I spoke it that I did not have any solid excuse, yet I did not take part in the battle. At that point the holy Prophet (PBUH) boycotted me on the command of Allah for fifty days. Afterwards, his words were: I was sitting as Allah the Sublime has mentioned in the holy Quran that my soul became straitened for me and the earth seemed constrained to me despite its spaciousness. All the sudden I heard a man announcing on the mount of Sulaa loudly: O Kaab bin Malik! Have a tiding. I fell prostrating and comprehended that ease has arrived. The Messenger of Allah (PBUH) did Elaan (announcement) of our forgiveness. ${ }^{9}$

The hadees plainly tells that Elaan / announcement was there in the holy Prophet's era.

5. Elaan of Lost Things in a Mosque

Hazrat Jabir (r.a) narrates that a man came to the Masjid to do Elaan (announce) about his missing thing. The Messenger of Allah (PBUH) said: You should never find that. 10

It manifests that Elaan as an announcement was a common term at that time.

\section{Missing object and Elaan}

The holy Prophet Muhammad (PBUH) was asked about a missing object of an unknown person if someone finds that what his duty is. He said: Do Elaan (announce) about it for a year. If a person comes and claims that, pass that to him, otherwise remember its bag and rope and eat it (or use it). If its owner comes after that, give him its alternative. ${ }^{11}$

There is an obvious proof of Elaan as an announcement.

\section{7. $\quad$ Elaan of Hazrat Noah (PBUH)}

The holy Quran narrated the statement of Hazrat Noah (PBUH) that reads: "And I did Elaan (announce) to them in public and I spoke to them secretly in private." 12

This verse establishes the fact that when people would speak to others in public and clarify the message to them openly was called as Elaan in the meaning of an announcement.

\section{Commercial Elaan i.e advertising in the Prophet Era}

As Elaan in the meaning of an announcement was a customary word similarly it was in vogue to use it as an advertising for selling goods. Here are some of the examples from the holy Prophet's era:

\section{Story of Grain Seller}

Hazrat Abu Huraira (r.a) reported that the holy Messenger of Allah (PBUH) walked by a heap of grain. He thrust his hand into it. His fingers got damp. He said: O Grain Seller! What is it? He said: O Messenger of Allah! It rained on it. The holy Prophet (PBUH) inquired: Why did you not exhibit the wet part so people could see? And he 
said furhter: "Whoever deceive us is none of us"13. In this hadees the holy Prophet (PBUH) objected on the practice of that grain seller as he felt deceit there, but he did not object on placing the grain on display. This was an old fashion of advertising. People used to put their selling items at that time before their shops where customers could see their goods and come to buy. The abovementioned hadees states loud and clear that the commercial advertising itself is permissible, but it should be far from deception and fraud.

\section{Hadees of Hazrat Dihya bin Khalifa Kalbi (r.a)}

Hazrat Jabir bin Abdullah (r.a) narrated that the holy Prophet (PBUH) was delivering sermon of Juma and a commercial caravan arrived from Sham (Syria). People went to the caravan and only twelve people stayed there. (In another narration I was one of them.) Allah the Greatest revealed these verses of the holy Quran:

"And when they see commerce or an amusement, they run for it and leave you standing. Say: What Allah has is far better than that commerce and then that amusement, and $\mathrm{He}$ is the best of providers"14. One another narration says that Hazrat Abu Bakar and Hazrat Umer (r.a) were among them. Kalbi and other scholars say that the one who brought the commercial goods was Hazrat Dihya bin Khalifa Kalbi (r.a) and there was a famine together with price hike. Further he added: They fetched all those things which were direly needed, like: Wheat and flour etc. So they came to a place in Madina called 'Ahjaar uz Zait'. They beat drum to advertise and inform people of their arrival. Then people went to them except the twelve men. ${ }^{15}$

There is an addition in another narration that the holy Prophet (PBUH) was giving sermon after the Juma Prayer. A man came and announced that Dihya bin Khalifa Kalbi had arrived with commercial goods. It was a custom of Hazrat Dihya bin Khalifa Kalbi's family that whenever he would come, they beat Daff (tambourine) to welcome him (or to advertise the commercial goods and inform them of their arrival). People (left sermon) and went to the goods and thought that not listening to the sermon was permissible. Allah the Sublime revealed this verse. (The verse of Surah Juma mentioned above.) ${ }^{16}$ The aforesaid citation establishes that one of the ways of advertising commercial goods was to beat Daff (tambourine) in the early days of Islam.

\section{Hadees of Hazrat Zahir}

Hazrat Anas (r.a) reported that there was a man called Zahir. He would bring gift for the holy Prophet (PBUH) from a village and the holy Prophet (PBUH) used to give him things when he would leave for his village. The holy Prophet (PBUH) said: 'Zahir is our village and we are his city.' He was beloved of the holy Prophet (PBUH), but he had not fair complexion.

Once the holy Prophet (PBUH) got closer to him and he was selling his goods. The Prophet (PBUH) embraced him from behind as he could not see him. He said: Leave me, who is this? Suddenly he recognized the holy Prophet (PBUH). He abandoned trying to get rid of his grip to the extent that he himself started trying to touch the chest of the holy Prophet (PBUH) with his back. The Messenger of Allah said: Who 
will purchase this boy? He said: O Messenger of Allah! Then you will find me of no value. The Prophet (PBUH) said: But you are not valueless in the sight of Allah. Or he said: You are too expensive in the sight of Allah. ${ }^{17}$

The words 'Who will purchase this boy?' are proof of an advertising in that era.

\section{Practices of the Companions in the Prophet's Era}

The companions of the holy Prophet (PBUH) habitually displayed their for-sale items and would walk in the streets of Madina to advertise them or invite people to pay attention to their goods. Sometimes, they would send their servants or slaves to fulfil this task. It was one of a primary way of the advertising then. No reaction of the holy Prophet (PBUH) is described in this regard. It will be considered as an approval of him (PBUH) in this connection. ${ }^{18}$

\section{Brokers and Commission Agents in the Prophet's Era}

The status of any advertising company is that of brokers and commission agents of old times. They are the medium between the seller and the buyer. Their relation become possible because of them. The brokers and commission agents worked for the seller as advertisers and received a wage thereupon. In the holy Prophet's era, there was brokerage and commission agency and he not only authorized it but also gave directives regarding them.

There is hadees of Hazrat Qais bin Abi Ghazra (r.a). He said: At the time of the holy Messenger of Allah (PBUH) we were called 'Samasira' (Brokers). When the holy Messenger of God (PBUH) passed by us; he called us with better name. He said: O group of merchants! Surely the financial transactions got polluted with nonsense and swear, so add charity to your transactions ${ }^{19}$. The holy Prophet (PBUH) pointed through this to the verse of the holy Quran: "Verily, the good deeds remove the evil ones. ${ }^{20}$

\section{Practice of Hazrat Ali (r.a)}

Hazrat Aqmer (R.A) stated: I saw Hazrat Ali bin Abi Talib (R.A) hoisting his sword to advertise for selling. He was saying: Who will buy this sword from me? I swear to Allah! I have eliminated many worries through this sword from the Messenger of Allah (PBUH). If I had money for clothing, I would never sell it. ${ }^{21}$

All the aforesaid references lead us to a conclusion that 'Advertising' was there at the advent of Islam and before.

\section{Shariah Ruling of the Advertising}

Four examples of the commercial advertising are quoted in the preceding heading. They were from the time of the holy Prophet (PBUH). They all explicitly show permissibility of the ADVERTING in Islam. Besides they make clear that advertising itself is allowed unless it includes something against the Islamic Shariah, like: Lies, deception, and obscenity etc. Some other proofs from the Islamic Shariah are cited here:

\section{Dialogue between Hazrat Yousaf (PBUH) and the King of Cairo}

Hazrat Yousaf (PBUH) had spent many years in the jail. When the king of Cairo saw a dream, Hazrat Yousaf (PBUH) was asked to interpret it. He not only told them the interpretation, but also he told them the escape plan. The king of Cairo was very pleased 
to hear that and desired a meeting with him. He firstly wanted to falsify all allegations which were claimed against him before the meeting. After that he came to the palace of the king. The king of Cairo had already been aware of his knowledge through the interpretation of the dream and the solution of the upcoming hardship. He further knew his honesty when all the accusations were established false. The king talked to him and got impressed. He said: 'from today you are an honorable, a faithful one in our sight. ${ }^{22}$ When the king wished to assign him a position, so Hazrat Yousaf (PBUH) stated: 'Appoint me over the treasures of the land, for I am careful guard and knowledgeable (of a job). ${ }^{23}$

\section{Communication of Hazrat Yousaf (PBUH) to His Brothers}

Similarly, when Hazrat Yousaf (PBUH) invested with the kingship of Cairo and his brothers came to him due to drought in their area and wanted to buy goods, he recognized them and persuaded them to bring their younger brother otherwise he would not deal with them. During that conversation he said: Do you not see that I give full measure (of grain) and I am the best of hosts? ${ }^{24}$

\section{Reasoning}

Allah the Al-Mighty has allowed to reveal one's good qualities when needed, like qualities of being knowledgeable, honest in measuring and hospitable are exposed in the story of Hazrat Yousaf (PBUH). Although the original ruling of Allah the Merciful regarding praising oneself is that it is forbidden. He said: 'Do not attribute purity to yourselves.' 25

This uncovers the fact that when a human is permitted to expose his good qualities at the time of need and he can praise himself, he should be allowed to praise his trade items with greater force, as there is no such evidence in the Islamic Shariah that forbids the praising of the trade items for sale, whereas there was proof against the praising oneself in normal circumstances. This commercial advertising is, in fact a praise of products, services and companies and it is meant to invite people to buy them.

\section{Rule: The Basic Rule in All Things is That They are Permissible.}

The advertising, in one aspect, works as a preamble for different transactions like sale, lease and so on. When all these matters are Islamically legal, advertising as a preamble should be authorized as well, because there is a principle in the Jurisprudence that the basic rule in all things is permissibility until there appears any proof to forbid it. ${ }^{26}$

\section{Advertising as a Transaction}

Advertising itself in another aspect is a transaction, because the parts of advertising are different transactions and it is a collection of all. The producer of a selling good or item enters the lease agreement with the advertising company. After the composition of the advertisement the producer buys time and a space from a TV Channel, Radio Channel or Newspaper etc. When all these transactions are allowed, the advertising which is combination of all these transactions, should be allowed as well.

\section{Islamic Shariah Avoids Hardship}

Everything that is a basic need of people, that relates to their financial benefit and 
outweigh others, the Shariah does not prohibit it because if it does it will be tantamount to imposing hardship upon them and harming them. Both are avoided by the Islamic Shariah. Allah the Almighty says: 'He had not imposed any hardship upon you'27 Allah the All-Beneficent said likewise: "Allah wants for you ease and He does not want you to suffer difficulties" 28 .

There is a hadees of Hazrat Ayesha (r.a) in the same way, that whenever the Prophet of Allah (PBUH) was given a choice between two things, he would choose the easier one if it was not a $\sin ^{29}$

Advertising is a need of people in current times and they need to buy stuff now and then. There are number of things available in any market to fulfil their needs. Keeping in view this scenario it becomes confusing for a person to choose the most suitable thing for his need and avoid a swindle. Therefore, most of the times he buys those things which he has seen in any advertisement and he has a blur picture of its qualities.

Besides the world has become a 'Global Village' and the production companies make things and consider the whole world their market. So, they try to advertise their goods worldwide and aim to make people use their products and get fascinated by them lifelong. To introduce their products far and wide they need effective advertising. Hence every production company needs an advertisement. That's why, advertising becomes a vital part of a socio-economic activities. Bearing this in mind if advertising is forbidden in the economic activities of the people, it will make them suffer. Whereas one of the main objectives of the Islamic Shariah is 'Avoidance from damage'. The Shariah has two laws for that:

1. لاضرر ولاضرار

2. الضرر يزال، Harm must be removed.'

In a nutshell, the cases of the advertising from the Traditions of the holy Prophet (PBUH) and bearing in mind importance and need of it in current times, it is clear that publishing ads and broadcasting them for the promotion of the goods or services is basically allowed unless something contradictory to Islam is added to it, like lies, deception, exaggeration, degrading of other's goods and display of half-naked women etc.

\section{Conclusion}

The advertising, along with its both meanings, was present in the time of the holy Prophet (PBUH). There are many examples in the holy Qur'an and the traditions of the holy Prophet (PBUH) that lead us to the permissibility of advertising. Moreover, there are some limits set by the Islamic Shariah which should never be crossed. The results of the above-mentioned discussion is summarized here:

A. The Arabic word 'Elaan' has two meanings.

1. A relation between a manufacturer of products and consumers and the goal of this relation is to enhance sale of the product.

2. When someone needs to guide people in some issue or attain a specific objective, he spreads it widely. 
B. The examples of the advertising are there in the holy Quran and Hadees.

C. Advertising is a legal act in the Islamic shariah and the evidences to approve it do exist.

\section{Refrences}

1. Surah an Nisa, 4:59

2. Surah an Nisa, 4:83

3. Al Mnasir, Ali Abdul Kareem Muhammad, Al Elanaat ut Tijariyah; Mufhoomuha wa Ahkamoha fil Fiqhil Islami, College of Higher Education in The University of Jordan, (2007), Footnote of Page: 19

${ }^{4}$.Google Translate, Retrieved Date: 19-08-2019. https://translate.google.com/?langpair=ar\%7Cen\# view= home\&op=translate\&sl=ar\&tl=en\&text=اعلان

${ }^{5}$.Kandalhawi, Muhammad Idrees, Sirat e Mustafa, Al Maarif Jamia Husainia Shahdadpur Sindh, NY, $\mathrm{V}: 1, \mathrm{P}: 392$

6. Bukhari, Muhammad bin Ismail, AlJama us Sahih, Dar Ibne Kaseer, Beirut, (1987) V3, P1420

7 Al Jawzi, Muhammad bin Abi Bakar ibn ul Qayyam, Zadul Maad, Muktaba tul Manaar Al Islamia Beirut, (1986), V:3, P:153

${ }^{8}$ Kandalhawi, Muhammad Idrees, Sirat e Mustafa, Al Maarif Jamia Husainia Shahdadpur Sindh, NY, V: $1, P: 441$

${ }^{9}$ Al Buti, Muhammad Saeed Ramzan, Fiqh us Sirah an Nabawiya, Darul Fikr Muaasir Beirut, (1991), P: 440

${ }^{10}$ An Nasai, Ahmed bin Shoib Abu Abdur Rahman, As Sunan, Maktab Al Mutbuaat Al Islamia Hulb, (1986), V: 2, P:48

${ }^{11}$ As Sajistani, Abu Dawood Suleman bin Ashaus, As Sunan, Darul Kitab Al Arabi Beirut, NY, V2, P65

${ }^{12}$ Surah an Nooh, 71:9

${ }^{13}$ At Tirmizi, Abu Esa Muhammad bin Esa, AlSunan, Dar Ehya Alturaas Alarabi Beirut, NY, V3, P606

${ }^{14}$ Surah Al Juma, 62:11

15 Al Qurtabi, Abu Abdullah Muhammad bin Ahmed, Al Jama Li Ahkam il Quraan, Darul Kutub Al Misriyya, Cairo, (1964) V: 18, P:109

16 abid, P: 110

${ }^{17}$ Abu Yala, Ahmed bin Ali, Al Musnad, Darul Mamoon lit Turaas, Damascus, (1984), V: 6, P: 173

18 As Slaheen, Abdul Majeed, Al Elanaat at Tijariah Ahkamoha wa Zawabituha fil Fiqh il Islami, Journal of Shariah and Law, University of UAE, (2004). V: 21, P: 35

${ }^{19}$ As Sajistani, Abu Dawood Suleman bin Ashaus, AlSunan, Darul Kitab Alarabi Beirut, NY, V3, P246

${ }^{20}$ Surah Hood, 11:114

${ }^{21}$ At Tubrani, Suleman bin Ahmed, Al Mujam Al Awsat, Darul Haramain Cairo, (1415 H), V:7, P:174

${ }^{22}$ Surah Al Yousaf, 12:54

${ }^{23}$ Surah Al Yousaf, 12:55

${ }^{24}$ Surah Al Yousaf, 12:59

${ }^{25}$ Surah an Najam, 53:32

${ }^{26}$ Azzam, Abdul Aziz Muhammad, Al Qawaid Al Fiqhiya, Darul Hadees Cairo, (2005), P: 109. Ibn e Abadin, Muhammad Amin, Rudul Muhtaar Al Durril Mukhtar, Darul Aalam il Kutub Reyad, (2003), V: 1, P: 221

${ }^{27}$ Surah Al Hujj, 22:78

${ }^{28}$ Surah Al Baqara, 2:185

${ }^{29}$ Bukhari, Muhammad bin Ismail, AlJame us Sahih, Dar Ibn e Kaseer, Beirut, (1987) V3, P1306. Muslim bin Hajjaj Qusheri, Al Jaama Al Sahih, Dar Ehya Alturaas Al Arabi Beruit, NY, V4, P1813

${ }^{30}$ Ali Haider, Durarul Hukkam Sharah Mujullatul Ahkam, Darulkutub Alilmiyyah Beruit, NY, V1, P32

${ }^{31}$ abid, P: 33 